\title{
PENERAPAN MODEL PEMBELAJARAN KOOPERATIF TIPE TGT (TEAMS GAMES TOURNAMENTS) DALAM MENINGKATKAN MOTIVASI BELAJAR SISWA
}

\author{
Sobandi \\ SD Negeri Wangkelang I Majalengka, Indonesia \\ sobandi56@gmail.com
}

\begin{abstract}
Learning motivation is very influential on learning outcomes achieved by students. The higher the motivation to learn students the higher the results will be obtained. At SDN Wangkelang I, based on observations, several students were identified as having low learning motivation. The author tries to apply a learning model that is thought to increase student motivation. The learning model is the Team Games Tournament (TGT) type of Cooperative learning model. The purpose of this study was to determine the increase in student motivation in Class V SDN Wangkelang I on Islamic Religious Education subjects. The method in this study uses classroom action research. This research was conducted in the teaching program in 2016/2017 at SDN Wangkelang I, with the research subjects of Grade $V$ Semester 1 students as many as 30 students, the special conditions of these students allow the level of ability and absorption of these students to vary greatly. The results showed the learning outcomes of Class $V$ students of SDN Wangkelang I, Banjaran Subdistrict, in terms of basic competencies regarding Interpreting QS Al Lahab and Al Kafirun, which experienced a significant increase after being implemented by the TGT (Teams Games Tournaments) Cooperative Learning Model. Thus it can be concluded that the application of the TGT (Teams Games Tournaments) Cooperative Learning Model can increase the motivation of students in class $V$ of SDN Wangkelang $I$..
\end{abstract}

Keywords: Learning Motivation, Islamic Religious Education, TGT Type Cooperative Learning Model

\section{ABSTRAK}

Motivasi belajar sangat berpengaruh terhadap hasil belajar yang dicapai siswa. Semakin tinggi motivasi belajar siswa semakin tinggi pula hasil yang akan diperoleh. Di SDN Wangkelang I, berdasarkan hasil observasi, teridentifikasi beberapa siswa memiliki motivasi belajar yang rendah. Penulis mencoba menerapkan suatu model pembelajaran yang diduga dapat meningkatkan motivasi belajar siswa. Model pembelajarn tersebut adalah Model pembelajaran Kooperatif tipe Team Games Tournament (TGT). Tujuan Penelitian ini adalah untuk mengetahui peningkatan motivasi belajar siswa Kelas V SDN Wangkelang I pada mata pelajaran Pendidikan Agama Islam. Metode dalam penelitian ini menggunakan penelitian tindakan kelas. Penelitian ini dilakukan pada program pengajaran tahun 2016/2017 di SDN Wangkelang I, dengan subyek penelitian siswa kelas V Semester 1 sebanyak 30 siswa, kondisi kekhususan siswa ini memungkinkan tingkat kemampuan dan daya serap siswa tersebut sangat bervariasi. Hasil penelitian menunjukkan hasil belajar siswa Kelas V SDN Wangkelang I Kecamatan Banjaran pada kompetensi dasar tentang Mengartikan QS Al Lahab dan Al Kafirun mengalami peningkatan yang cukup signifikan setelah diterapkan Model Pembelajaran Kooperatif Tipe TGT (Teams Games Tournaments). Dengan demikian dapat disimpulkan penerapan Model Pembelajaran Kooperatif Tipe TGT (Teams Games Tournaments) dapat meningkatkan motivasi belajar siswa kelas V SDN Wangkelang I.

Kata Kunci: Motivasi Belajar, Pendidikan Agama Islam, Model Pembelajaran Kooperatif Tipe TGT

Submitted November 7, 2019 | Revised December 3, 2019 | Accepted December 5, 2019

\section{Pendahuluan}

Melihat dari perolehan nilai ketuntasan belajar di SDN Wangkelang I tentang Standar Kompetensi Menghafal Al-Qura'an Surah-Surah Pendek pilihan dengan Kompetensi Dasar Mengartikan QS Al Lahab dan Al Kafirun tersebut dengan SKBM 75 yang ternyata tidak dapat 
dicapai oleh siswa secara optimal untuk mata pelajaran Pendidikan Agama Islam. Perolehan ketuntasan belajar yang demikian ini, dapat disebabkan akibat pelaksanaan metode belajar siswa yang kurang bermakna.

Kondisi tersebut membangkitkan minat penulis selaku pengajar di SDN wangkelang I untuk berniat mengkaji mengenai model belajar yang tepat bagi siswa di Kelas $\mathrm{V}$ tentang Menghafal Al-Qura'an Surah-Surah Pendek pilihan SDN Wangkelang I tersebut, salah satunya adalah dengan mencoba memahami model pembelajaran dengan melalui Model Pembelajaran Kooperatif Tipe TGT yang menurut hemat peneliti dapat diterapkan pada peserta didik, dimana pengajaran kooperatif adalah termasuk dalam rumpun teori belajar berupa pendekatan konstruktivis yang berdasar pada prinsip-prinsip pembuatan/pengajuan pertanyaan (Nur dan Wikandari, 2000: 16).

Menurut Purwanto (2004: 64-65), apa saja yang diperbuat manusia, yang penting maupun kurang penting, yang berbahaya maupun yang tidak mengandung resiko, selalu ada motivasinya. Ini berarti, apa pun tindakan yang dilakukan seseorang selalu ada motif tertentu sebagai dorongan ia melakukan tindakannya itu. Jadi, setiap kegiatan yang dilakukan individu selalu ada motivasinya. Motivasi dapat diklasifikasikan menjadi dua: (1) motivasi intrinsik, yaitu motivasi internal yang timbul dari dalam diri pribadi seseorang itu sendiri, seperti sistem nilai yang dianut, harapan, minat, cita-cita, dan aspek lain yang secara internal melekat pada seseorang; dan (2) motivasi ekstrinsik, yaitu motivasi eksternal yang muncul dari luar diri pribadi seseorang, seperti kondisi lingkungan kelas-sekolah, adanya ganjaran berupa hadiah (reward) bahkan karena merasa takut oleh hukuman (punishment) merupakan salah satu faktor yang mempengaruhi motivasi).

Menurut Slavin (1995:15) pembelajaran kooperatif tipe TGT terdiri dari 5 langkah tahapan yaitu: Penyajian kelas (class precentation), belajar dalam kelompok (Team), permainan (games), pertandingan (tournament), dan penghargaan kelompok (team recognition). Berdasarkan hasil penelitian yang telah dilakukan oleh Dwikoranto (2009) memperlihatkan hasil bahwa hasil belajar siswa meningkat cukup signifikan setelah digunakan. Model pembelajaran Teams Games Tournament. Pembelajaran kooperatif model TGT adalah salah satu tipe atau model pembelajaran kooperatif yang mudah diterapkan, melibatkan aktivitas seluruh siswa tanpa harus ada perbedaan status, melibatkan peran siswa sebagai tutor sebaya dan mengandung unsur permainan dan reinforcement. Aktivitas belajar dengan permainan yang dirancang dalam pembelajaran kooperatif model TGT memungkinkan siswa dapat belajar lebih rileks disamping menumbuhkan tanggung jawab, kerjasama, persaingan sehat dan keterlibatan belajar.

Model pembelajaran kooperatif tipe Teams Games Tournament (TGT) salah satu tipe atau model pembelajaran kooperatif yang mudah diterapkan, melibatkan aktivitas seluruh siswa tanpa harus ada perbedaan status, melibatkan peran siswa sebagai tutor sebaya dan mengandung unsur permainan dan penguatan (Yudianto, 2014). model pembelajaran kooperatif dimana kegiatan belajar siswa diawali dengan memperhatikan penjelasan guru di depan kelas (presentasi kelas), team (belajar kelompok), games (memainkan permainan), kemudian tournament (turnamen akademik) dan terakhir rekognisi tim (Mulyani, 2018). Pembelajaran dengan menggunakan Kooperatif model TGT, pada awal pembelajaran guru menyampaikan materi dalam penyajian kelas, biasanya dilakukan dengan pengajaran langsung atau dengan ceramah, diskusi yang dipimpin 
guru. Pada saat penyajian kelas ini siswa harus benar-benar memperhatikan dan memahami materi yang disampaikan guru, karena akan membantu siswa bekerja lebih baik pada saat kerja kelompok dan pada saat game karena skor game akan menentukan skor kelompok. Kelompok biasanya terdiri dari 4 sampai 5 orang siswa yang anggotanya heterogen dilihat dari prestasi akademik, jenis kelamin dan ras atau etnik. Fungsi kelompok adalah untuk lebih mendalami materi bersama teman kelompoknya dan lebih khusus untuk mempersiapkan anggota kelompok agar bekerja dengan baik dan optimal pada saat game. Game dala pembelajaran ini terdiri dari pertanyaan-pertanyaan yang dirancang untuk menguji pengetahuan yang didapat siswa dari penyajian kelas dan belajar kelompok. Kebanyakan game terdiri dari pertanyaan-pertanyaan sederhana bernomor. Siswa memilih kartu bernomor dan mencoba menjawab pertanyaan yang sesuai dengan nomor itu. Siswa yang menjawab benar pertanyaan itu akan mendapat skor. Skor ini yang nantinya dikumpulkan siswa untuk turnamen mingguan. Biasanya turnamen dilakukan pada akhir minggu atau pada setiap unit setelah guru melakukan presentasi kelas dan kelompok sudah mengerjakan lembar kerja. Turnamen pertama guru membagi siswa ke dalam beberapa meja turnamen. Tiga siswa tertinggi prestasinya dikelompokkan pada meja I, tiga siswa selanjutnya pada meja II dan seterusnya.

Guru kemudian mengumumkan kelompok yang menang, masing-masing team akan mendapat sertifikat atau hadiah apabila rata-rata skor memenuhi kriteria yang ditentukan. Team mendapat julukan "Super Team" jika rata-rata skor 45 atau lebih, "Great Team" apabila rata-rata mencapai 40-45 dan "Good Team" apabila rata-ratanya 30-40.

\section{Metode Penelitian}

Penelitian ini menggunakan metode Penelitian Tindakan Kelas (PTK), yaitu penelitian tindakan yang dilakukan untuk memperbaiki proses belajar mengajar guna meningkatkan hasil belajar yang lebih baik dari sebelumnya. Menurut Aqib (2011), penelitian tindakan kelas adalah penelitian yang dilakukan oleh guru di kelasnya sendiri melalui refleksi diri dengan tujuan untuk memperbaiki kinerjanya sehingga hasil belajar siswa meningkat.

Penelitian ini dilakukan sebanyak tiga skilus dimulai bulan Oktober 2017 hingga November 2017. Secara umum siklus penelitian ini melalui langkah-langkah kegiatan perencanaan, pelaksanaan, pengamatan dan refleksi kegiatan. Setiap siklus berlangsung sesuai dengan jumlah tatap muka dalam sub konsep yang dipelajari. Ketika proses pembelajaran berlangsung guru mengamati dan mencatat kegiatan siswa dalam proses belajar mengajar. Kemudian data yang diperoleh dianalisis setiap akhir kegiatan belajar mengajar. Perencanaan tindakan meliputi analisa materi pembelajaran penyusunan rencana pembelajaran dan penyusunan model pembelajaran yang berpedoman pada rancangan pembelajaran bagi siswa.

Adapun putaran dari pelaksanaan penelitian tindakan kelas dapat digambarkan sebagai berikut (Arikunto, dkk, 2005): 


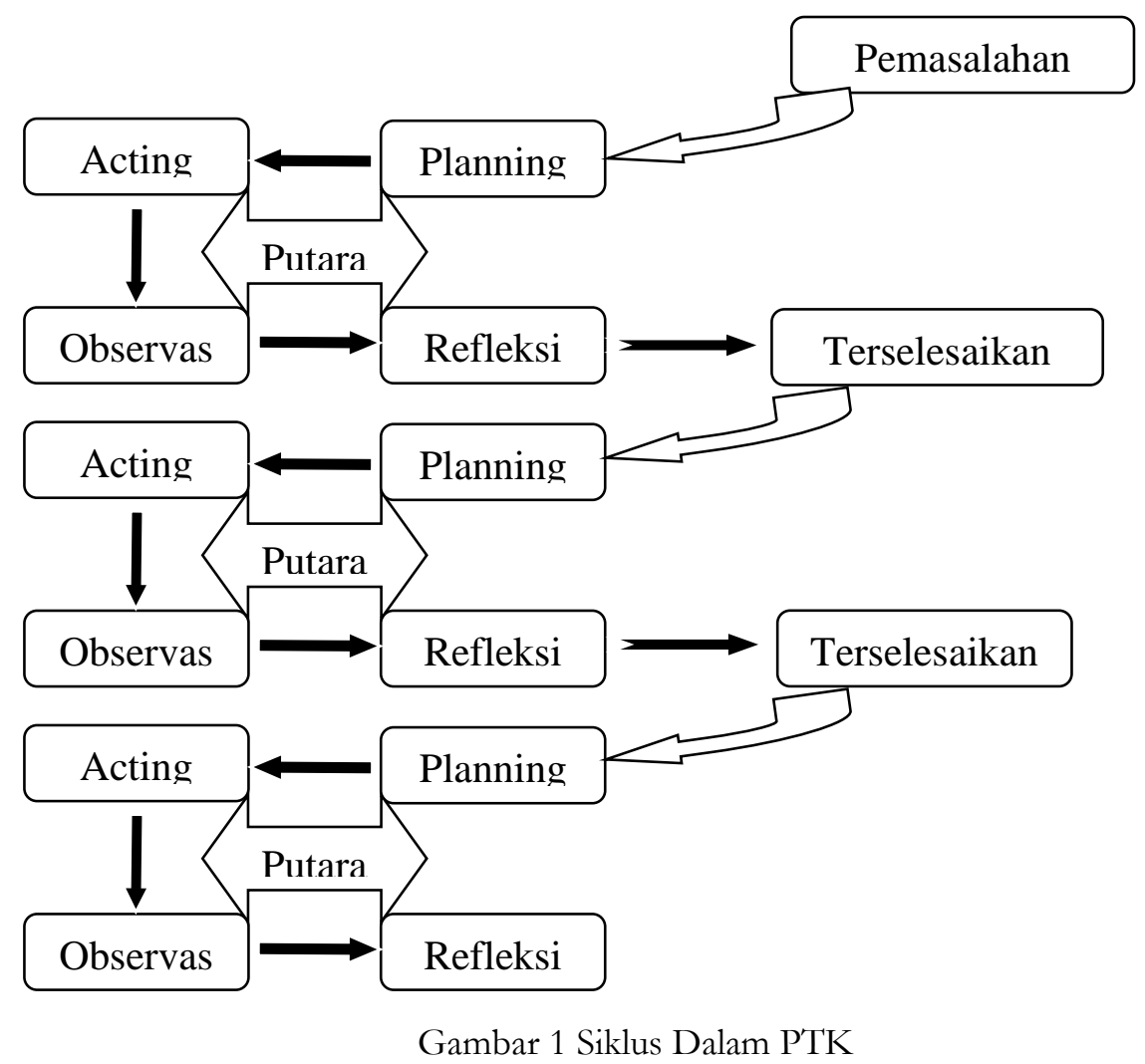

Bentuk penelitian yang disajikan dalam karya tulis ini meliputi data utama yang meliputi data hasil belajar siswa setelah mengikuti kegiatan pembelajaran berdasarkan pembelajaran dengan menggunakan Model Pembelajaran Kooperatif Tipe TGT. Adapun data pendukungnya meliputi data respon siswa terhadap kegiatan pembelajaran dengan menggunakan Model Pembelajaran Kooperatif Tipe TGT dan penampilan guru dalam pembelajaran.

\section{Hasil dan Pembahasan}

Keadaan awal sebelum pelaksanaan pembelajaran dengan menggunakan Model Pembelajaran Kooperatif Tipe TGT pada materi Pendidikan Agama Islam di SDN Wangkelang I Kelas V Semester 1 yang membahas Pada Kompetensis Dasar Mengartikan QS Al Lahab dan Al Kafirun meliputi : Ceramah, Penugasan Diskusi, Tanya jawab. Hasil tes ulangan Pendidikan Agama Islam ini memperoleh rata-rata nilai 72, ketuntasan secara klasikal $66 \%$, dan terdapat 4 siswa yang tidak tuntas.

1. Pelaksanaan Siklus I

Perencanaan pada siklus I yang dilakukan Pada Kompetensi Dasar Mengartikan QS Al Lahab dan Al Kafirun Perangkat pembelajaran yang disiapkan meliputi : Rencana Pembelajaran, Soal dan Evaluasi. Dalam RP dirancang dengan kegiatan pendahuluan yang meliputi : Apersepsi; Menjelaskan tujuan pembelajaran. Pre Tes; Kegiatan inti yang direncanakan antara lain : 
Menjelaskan materi secara singkat; Membentuk kelompok, Melaksanakan kegiatan diskusiMengadakan presentasi : sebelum kegiatan pembelajaran ditutup pada siklus I ini diadakan kuis sebanyak 10 soal.

Pembelajaran PAI dengan model TGT dilaksanakan melalui kegiatan guru pada saat pembelajaran antara lain : menyampaikan informasi tentang materi Pendidikan Agama Islam Pada Kompetensi Dasar Mengartikan QS Al Lahab dan Al Kafirun, kegiatan praktek menggunakan Model Pembelajaran Kooperatif Tipe TGT diarahkan untuk melatih siswa memecahkan masalahmasalah yang dihadapi oleh siswa dengan harapan untuk mencapai tujuan pembelajaran yang telah ditetapkan. Guru membimbing siswa dan membahas permasalahan, memberikan bantuan bila diperlukan, dan mengawasi kegiatan siswa. Setelah diadakan kuis guru memberikan pengumuman pada siswa yang memperoleh nilai tertinggi. Kemudian ditutup dengan membimbing memberikan kesimpulan dan memberi tugas rumah untuk minggu depan.

Hasil pengamatan pada siklus I terlihat adanya sebuah kenaikan jumlah siswa yang tuntas hasil belajarnya. Nilai rata-rata yang dicapai pada UH awal sebesar 72, sedangkan pada siklus I 72 . Ketuntasan klasikal pada UH awal hanya mencapai $66 \%$, pada siklus I ini menjadi $61 \%$. Keterampilan siswa dalam melakukan Model Pembelajaran Kooperatif Tipe TGT pada siklus I yaitu : Mendengarkan penjelasan guru (Sedang), Menjawab pertanyaan guru (Banyak), Mencatat materi penting (Sedang), Memperhatikan permasalahan (Banyak), Mendiskusikan tugas dari guru (Sedang), Bertanya kepada guru, (Sedikit), Mengumpulkan hasil belajar kelompok (Banyak)

Berdasarkan hasil pengamatan yang telah dilakukan dapat di evaluasi/ refleksi dengan ditemukan hambatan seperti : 1) Sebagian siswa ada yang terlalu mendominasi dalam diskusi kelompok dalam menjawab pertanyaan sehingga kesempatan teman untuk menjawab pertanyaan masih belum optimal.2) Penjelasan guru pada materi pelajaran dianggap cukup menyita waktu sehingga perlu dikurangi pada siklus berikutnya.

2. Pelaksanaan Siklus II

Perencanaan pada siklus II dengan materi yang akan dibahas dibahas Pada Kompetensi Dasar Mengartikan QS Al Lahab dan Al Kafirun menyiapkan perangkat yang meliputi diantaranya melanjutkan rencana pembelajaran pada siklus I, Soal dan Evaluasi dengan 10 soal. Berdasarkan refleksi pada siklus I maka pada tindakan II waktu untuk memberikan penjelasan kepada murid perlu dikurangi dan kesempatan untuk memberikan giliran kepada siswa lain dalam menjawab pertanyaan masih bisa dioptimalkan.

Pelaksanaan tindakan guru pada siklus II ini telah sesuai dengan yang direncanakan pada Rencana Pembelajaran, sehingga tidak banyak memakan waktu. Sebelum kegiatan pembelajaran selesai diadakan kuis dan pemberian penghargaan kepada kelompok yang memperoleh nilai terbaik.

Berdasarkan observasi pada siklus II ditemukan adanya kenaikan jumlah siswa yang tuntas belajarnya. Pada siklus I ketuntasan belajar secara klasikal $61 \%$, siklus II naik menjadi $83 \%$ dan nilai rata-rata siklus I sebesar 72, siklus II menjadi 77 . Siswa yang tidak tuntas pada siklus II ada 5 anak. Keterampilan siswa dalam melakukan Model Pembelajaran Kooperatif Tipe TGT meliputi : Mendengarkan penjelasan guru (Sedang); Menjawab pertanyaan guru (Banyak); Mencatat materi 
penting (Banyak); Memperhatikan permasalahan (Banyak); Mendiskusikan tugas dari guru (Sedikit); Bertanya kepada guru, (Banyak); Mengumpulkan hasil belajar kelompok (Banyak).

Berdasarkan refleksi pada siklus II ini ditemukan permasalahan di antaranya penyediaan buku bacaan selain buku paket bagi siswa masih terbatas oleh karena itu siswa yang tidak memiliki buku bacaan dianjurkan untuk pinjam di perpustakaan sekolah dan pihak sekolah dapat mempersiapkan atau memperbanyak buku bacaan selain buku bacaan Pendidikan Agama Islam yang penting bisa berkaitan dengan masalah kemerdekaan. Masih ada 4 siswa yang belum tuntas belajarnya. Bimbingan kepada siswa yang belum tuntas pada saat KBM perlu dioptimalkan.

3. Pelaksanaan Siklus III

Perencanaan Pada siklus II dengan materi yang diajarkan adalah Ilmu Pengetahuan Sosial Pada Kompetensi Dasar Mengartikan QS Al Lahab dan Al Kafirun Perangkat pembelajaran yang disiapkan meliputi : Rencana awal, Evaluasi dan 10 soal. Rencana pembelajaran dan pelaksanaan kuis, secara garis besar masih sama dengan siklus I dan II. Namun berdasarkan refleksi siklus II terdapat 7 siswa yang belum tuntas, pada siklus III ini siswa tersebut diberikan bimbingan yang lebih baik secara khusus. Penyediaan buku bacaan selain buku Pendidikan Agama Islam dilengkapi dari pinjaman perpustakaan.

Hasil observasi pada siklus III menunjukkan ada peningkatan. Nilai rata-rata pada siklus II 77, pada siklus III naik menjadi 84 . Presentasi ketuntasan klasikal naik dari $83 \%$ menjadi $100 \%$. Keterampilan siswa dalam melakukan Model Pembelajaran Kooperatif Tipe TGT rata-rata banyak. Data respon siswa terhadap KBM rata-rata mencapai 83,33 \%. Berdasarkan hasil supervisi Kepala Sekolah skor rata-rata mencapai 3,6, angka ini tergolong baik. Hasil ulangan harian siswa pada UH awal 72, sedangkan pada UH akhir mencapai nilai 86 . Ketuntasan belajar klasikal 100 $\%$.

Berdasarkan hasil refleksi pada siklus III ini menunjukkan adanya peningkatan dari berbagai hal. Tetapi berdasarkan refleksi siklus III ini masih ditemukan permasalahan buku referensi siswa dan guru kurang. Oleh karena itu pengadaan buku referensi perlu diperbanyak selain buku paket sangat diperlukan. Saat presentasi hasil melakukan Model Pembelajaran Kooperatif Tipe TGT tidak tersedia sarana dengan lengkap. Untuk ketercapaian tujuan maka perlu adanya sarana pendukung agar kegiatan pembelajaran dapat berlangsung lebih optimal.

Pembelajaran kooperatif model TGT adalah salah satu tipe atau model pembelajaran kooperatif yang mudah diterapkan, melibatkan aktivitas seluruh siswa tanpa harus ada perbedaan status, melibatkan peran siswa sebagai tutor sebaya dan mengandung unsur permainan dan reinforcement. Aktivitas belajar dengan permainan yang dirancang dalam pembelajaran kooperatif model TGT memungkinkan siswa dapat belajar lebih rileks disamping menumbuhkan tanggung jawab, kerjasama, persaingan sehat dan keterlibatan belajar. Pembelajaran dengan menggunakan Model Pembelajaran Kooperatif Tipe TGT mampu meningkatkan prestasi belajar siswa. Peningkatan prestasi belajar itu dapat dilihat dari hasil kuis dari siklus I, siklus II dan siklus III bahkan dapat dilihat dari hasil UH. Dengan menggunakan Model Pembelajaran Kooperatif Tipe TGT ini mampu meningkatkan aktifitas siswa dalam pembelajaran, dengan demikian dalam KBM tidak berpusat pada guru lagi. 


\section{Kesimpulan}

Hasil belajar siswa Kelas V SDN Wangkelang I Kecamatan Banjaran pada kompetensi dasar tentang Mengartikan QS Al Lahab dan Al Kafirun dapat mengalami peningkatan yang cukup signifikan setelah diterapkan kegiatan pembelajaran melalui Model Pembelajaran Kooperatif Tipe TGT (Teams Games Tournaments) 2) Nilai rata-rata pemahaman siswa dalam memperhatikan permasalahan, pada siklus pertama sebesar 72 pada siklus kedua pada siklus kedua sebesar 77 sedangkan pada siklus ketiga sebesar 84, tergolong baik demikian juga tentang ketuntasan belajar pada siklus pertama $61 \%$ dan pada siklus kedua menjadi 83. \% sedangkan pada siklus ketiga menjadi $100 \% 3$ ) Aktifitas siswa selama mengikuti kegiatan pembelajaran dapat meningkat sehingga kegiatan pembelajaran menjadi lebih berpusat pada siswa. Dalam penggunaan "Model Pembelajaran Kooperatif Tipe TGT (Teams Games Tournaments)" guru hendaknya juga memperhatikan pentingnya pengelolaan kelas. Hal ini demi kelancaran proses pembelajaran. Sebab walaupun dalam pembelajaran sudah menggunakan media bergambar yang baik namun jika dalam mengelola kelas kurang baik, maka proses pembelajaran akan terganggu dan hasilnya kurang memuaskan.

\section{Daftar Pustaka}

Aqib, Zainal, dkk. 2011. Penelitian Tindakan Kelas untuk Guru SD, SLB, dan TK. Bandung: Yrama Widya.

Arikunto, Suharsimi, dkk, (2005). Penelitian Tindakan Kelas. Bandung : Bumi Aksara.

Dwikoranto, (2009). Keefektifan Model Pembelajaran Kooperatif Tipe Teams Games Tournament ( Tgt) Pada Pembelajaran Fisika SMA. Dalam jurnal Pendidikan Matematika dan Sains, Vol 14, No 1. Surabaya

Ihsan, Fuad.(1996). Dasar-Dasar Kependidikan. Jakarta : PT. Rineka Cipta

Mulyani, dkk. (2018). Penerapan Model Pembelajaran Kooperatif Team Games Tournament (Tgt) Untuk Meningkatkan Kemampuan Kerja Sama Siswa Sekolah Dasar. Jurnal Pendidikan Guru Sekolah Dasar, Vol. III No. II, Agustus 2018, hlm. 38-45

Mulyasa. (2007). Menjadi Guru Profesional. Bandung: Penerbit PT Remaja Rosdakarya

Nur dan Wikandari, (2000). Strategi Inovasi Belajar Mengajar, Jakarta : PT. Rineka Cipta.

Purwanto. (2004). Ilmu Pendidikan Teoritis dan Praktis. Bandung: PT. Remaja Rosdakarya

Sardiman, A.M. (2004). Interaksi dan Motivasi Belajar Mengajar. Jakarta : Rajawali Pers.

Slavin, (1995). Model-Model Pembelajaran. Jakarta

Sujana, Nana. (2001). Tuntunan Penyusunan Karya Ilmiah. Bandung : Sinar Baru Argensindo. 
Yudianto, dkk. (2014). Model Pembelajaran Teams Games Tournament Untuk Meningkatkan Hasil Belajar Siswa SMK. Journal of Mechanical Engineering Education, Vol.1, No.2, Desember 2014 